NATIONAL AND LOCAL TAXATION 
Macmillan Building and Surveying Series

Building Technology

Ivor H. Seeley

Building Maintenance

Ivor H. Seeley

Building Quantities Explained

Ivor H. Seeley and R. Winfield

Introduction to Valuation

D. Richmond

National and Local Taxation

Michael Rayner

The British Construction Industry: an introduction

Dennis F. Dolan

Urban Land Economics

P. N. Balchin and J. L. Kieve

Related Macmillan Titles

Law for the Construction Industry

J. R. Lewis

Administrative Law for the Construction Industry

J. R. Lewis 


\section{NATIONAL AND LOCAL TAXATION}

\section{MICHAEL RAYNER F.R.I.C.S.}

Principal Lecturer,

Department of Surveying,

Trent Polytechnic
(Special Rating (Diploma) 
All rights reserved. No part of this publication may be reproduced or transmitted, in any form or by any means, without permission.

First published 1978 by

THE MACMILLAN PRESS LTD

London and Basingstoke.

Associated companies in Delhi Dublin

Hong Kong Johannesburg Lagos Melbourne

New York Singapore and Tokyo

Typeset in 10/12 Times by

Reproduction Drawings Ltd, Sutton, Surrey and printed in Great Britain by

Redwood Burn Limited

Trowbridge \& Esher

British Library Cataloguing in Publication Data

Rayner, Michael

National and local taxation.-(Macmillan

building and surveying series).

1. Taxation-Great Britain

I. Title

$336.2^{\prime} 00942 \quad$ HJ2619

ISBN 978-0-333-23318-4 ISBN 978-1-349-03608-0 (eBook) DOI 10.1007/978-1-349-03608-0

This book is sold subject to the standard conditions of the Net Book Agreement.

The paperback edition of this book is sold subject to the condition that it shall not, by way of trade or otherwise, be lent, resold, hired out, or otherwise circulated without the publisher's prior consent in any form of binding or cover other than that in which it is published and without a similar condition including this condition being imposed on the subsequent purchaser. 
To the memory of my parents 


\section{CONTENTS}

Preface xiii

I NATIONAL TAXATION 1

1 Taxation in the United Kingdom 3

National Taxation: Administration $\quad 3$

Current Direct Taxes $\quad 4$

Tax Planning $\quad 5$

Income Tax: The Legal Basis $\quad 5$

Income Tax Liability $\quad 6$

Nature of Income $\quad 6$

The Tax Year 6

Method of Assessment $\quad 7$

Appeals against Assessment $\quad 7$

$\begin{array}{ll}\text { Surtax } & 7\end{array}$

Allowances or Deductions $\quad 7$

Rates of Income Tax $\quad 8$

2 Income Tax Schedules A, B and C 9

Income Tax: Schedule A $\quad 9$

Schedule A: calculation of liability-Allowable deductions

from rents-Allowable deductions from other receipts-

Pooling of rental income-Expenditure on agricultural land-

Property managed as one estate-Owner-occupied property--

Taxation of premiums-Top slicing relief-Relief for premiums

taken by sub-lessee-Other payments treated as premiums-

Capital allowances-Schedule A: Time of assessment-Rents

and other receipts from property paid to companies

Schedule B

$\begin{array}{ll}\text { Schedule C } & 16\end{array}$

3 Income Tax Schedules D and E 17

$\begin{array}{ll}\text { Income Tax: Schedule D } & 17\end{array}$

Schedule D: The basis of assessment-Allowances against profitsPension contributions for self-employed individuals-The assessment of a new business--The assessment of a closing business-Taxation of a partnership-Changes within partnerships 
Nature of pay-Employer's return and the collection of taxes-

The taxation of personal incomes-Mortgage interest

4 Corporation Tax and Capital Allowances 24

Corporation Tax

Taxable income-Allowances-Capital allowances-

Basis of assessment-Rates of Corporation Tax-Payment

of Corporation Tax-Tax on dividends and distributions-

Close companies

Capital Allowances

Types of allowance - Who may claim capital allowancesIndustrial buildings-Initial allowances-Writing down allowanceMachinery and plant-Current allowances on machinery and plant-Claimants-Mineral properties and oil wells-Mineral depletion allowance-Agricultural and forestry land and buildingsScientific research allowance, knowhow and patents-

'Basis' period for capital allowances

5 Capital Gains Tax

History and Legislation $\quad 33$

Types of Asset $\quad 33$

Nature of Disposals $\quad 33$

Definition of 'Gain'

Liability for Capital Gains Tax $\quad 34$

$\begin{array}{ll}\text { Exemptions } & 34\end{array}$

'Roll-over' Provisions, FA 1965, s 33

Calculating Capital Gains $\quad 35$

Capital gains on freeholds-Freehold land held on 6 April 1965

Value Increased by Expenditure after Acquisition

Increase in value by expenditure incurred before April 1965-

Increase in value by expenditure after April 1965

Disposal of Part of an Asset

Gains from part disposal-Gains from disposal of part

Small Disposals

Capital Gains on Leaseholds $\quad 42$

Disposal of Short Leases $\quad 42$

Premiums on Short Leases $\quad 43$

Disposals of Long Leases $\quad 45$

Other Leasehold Transactions $\quad 45$

Disposals of Stocks and Shares 45

Losses under Capital Gains Tax, FA 1965, s 23

Wasting Assets 45 
Woodlands $\quad 45$

Rate of Capital Gains Tax $\quad 46$

Administration of the Tax $\quad 46$

6 Capital Transfer Tax 47

History $\quad 47$

Liability to Tax $\quad 47$

Effective Date of the Tax $\quad 47$

Administration, FA 1975, s 19, Schedule 4 48

The Basis of Capital Transfer Tax, FA 1975, s 20

Interrelation between Capital Gains and Capital Transfer Tax 48

Liability on Notional Disposals, FA 1975, Schedule 5

Exemptions and Reliefs, FA 1975, s 29, Schedule 6

Exempt transfers-Exempt gifts-Provisional exemptions-

Special cases-Reliefs

Property Liable to Tax

Valuation of Land for Capital Transfer Tax, FA 1975,

Schedule 10

Settling Values for Capital Transfer Tax $\quad 51$

Valuation of Agricultural Land, FA 1975, Schedule 8

Calculation of agricultural relief-Farming companies

Quick Succession Relief $\quad 54$

Limitation on Value $\quad 54$

Rates of Tax $\quad 54$

7 Development Land Tax

History and Structure $\quad 55$

Liability for DLT $\quad 55$

Operation of DLT $\quad 55$

Time of disposals $\quad 56$

Exemptions and Reliefs $\quad 57$

Calculation of Realised Development Value $\quad 59$

Definitions $\quad 61$

Current use value or CUV (DLTA, s 7)-Development valueConsideration for the grant of a lease (DLTA, Schedule 2, paragraph 26)-Improvements (DLTA, Schedule 3, paragraph 1)

-Relevant improvements (DLTA, Schedule 3, paragraph 2)$A$ major interest in land (DLTA, s 2)-Market value (DLTA, $s$ 7)-Market value immediately before a project of material development is begun-Material development (DLTA, s 7)Project of material development

Practical Examples $\quad 62$

Rates of Tax and Administration $\quad 67$

$\begin{array}{ll}\text { Interaction with Other Taxes } & 67\end{array}$ 
$8 \quad$ Rating in General and Rating Authorities 71

$\begin{array}{ll}\text { Historical Background } & 71\end{array}$

$\begin{array}{ll}\text { Rating Authorities } & 72\end{array}$

$\begin{array}{ll}\text { Precepting Authorities } & 72\end{array}$

$\begin{array}{ll}\text { Making the Rate } & 73\end{array}$

$\begin{array}{ll}\text { Appeal against the Rate } & 73\end{array}$

Who is to be Rated $\quad 74$

$\begin{array}{ll}\text { Collecting the Rate } & 75\end{array}$

Payment by instalments-Rates paid by mistake

and refunds-Default in rate payment

Rating of Empty Premises $\quad 76$

Differential Domestic Rate and Rate Rúbates $\quad 78$

9 Rateable Occupation $\quad 79$

$\begin{array}{ll}\text { The Concept of Rateable Occupation } & 79\end{array}$

Actual occupation-Exclusive occupation-Beneficial

occupation--Permanent occupation-Practical considerations

The Unit of Property to be Assessed $\quad 83$

Practical considerations

Reliefs and Exemptions $\quad 85$

10 The Valuation List and its Making $\quad 87$

$\begin{array}{ll}\text { The Valuation Officer } & 87\end{array}$

$\begin{array}{ll}\text { The Date of the Valuation Lists } & 87\end{array}$

The Contents of the Valuation List $\quad 87$

$\begin{array}{ll}\text { Making the Valuation List } & 87\end{array}$

Rent returns

Surveys and Referencing $\quad 89$

$\begin{array}{ll}\text { Valuation } & 90\end{array}$

Inspection of the Valuation List 90

The Rating Authority and the Valuation List $\quad 91$

11 Alterations to the Valuation List and Appeals 92

Proposals $\quad 92$

Proposals by the Valuation Officer (VO proposals)-

Proposals by aggrieved persons-What constitutes 'service'

Practical Considerations

Unopposed proposals--Directions-The effective date of proposals

Local Valuation Panels and Courts

The hearing-Evidence before the court: Rent returns-..

The decision of the court 
12 The Basis of Assessment and Methods of Valuation 101

Rateable Value, Net Annual Value and Gross Value

Definition of gross value and net annual value-Which hereditaments are assessed to $G V$ or NAV-The

hypothetical tenant-The hypothetical landlord

Principles of Valuation

The time of the valuation

Methods of Assessment

Rental comparison-The contractor's method-The

profits or accounts method-Valuation by comparable

assessments $\cdots$ Assessments by formula

13 Valuation of Dwellings, Shops and Offices

Dwelling Houses

Houses

Agricultural Dwelling Houses

Flats

Shops

Special problems

Offices

14 Factories and Warehouses; Contractor's Method Valuation;

Profits Method Valuation

Factories and Warehouses

Plant and machinery

Valuation by the Contractor's Test

Valuation by the Profits Test

Miscellaneous Properties

Schools-Polytechnics, universities and colleges-

Licensed premises-Mineral hereditaments-Property

owned by local authorities

Appendix A Current Rates of Income Tax and Personal Allowances

Investment Income Surcharge

Personal Allowances

Changes in Rates of Income Tax and Personal Allowances

Appendix $B$ Rates of Capital Transfer Tax

Appendix C Statutory Deductions to Convert Gross Value to Rateable Value 137 
Appendix D Various Properties and Methods of Assessment

Appendix $E$ Index of Cases

Bibliography

Taxation

141

Rating

141

General

Index

143 


\section{PREFACE}

It has been said, with truth, that the law and practice of taxing property is of hideous complexity. However that may be, the subject is of importance to surveyors and they are examined in it. So this book has been written for student surveyors, and follows the requirements of the syllabus of both the Royal Institution of Chartered Surveyors and the Incorporated Society of Valuers and Auctioneers. I also hope that it will be of use to students for the various degrees and diplomas in estate surveying and kindred subjects awarded by polytechnics and universities in the United Kingdom and elsewhere.

In the first part of the book I have dealt in varying degrees of detail with national taxation, giving the greatest emphasis to those aspects of taxation that are dealt with by surveyors. The law and practice here apply to the United Kingdom. In the second part of the book I have dealt in rather greater depth with local taxation, that is, rates. Here the law and practice apply only to England and Wales, since Scotland and Ulster have their own similar but divergent systems. In both parts the law is as at 31 December 1977.

A full bibliography, with notes for further reading is included: the student should find this helpful when he enters practice and needs to go into various aspects of the subject in greater depth than is appropriate in a primer such as this. Throughout I have used the male pronoun when I know very well that I should have said 'he or she'; but old habits die hard!

A number of further points should be noted.

(1) All titles of statutes have been abbreviated in the book, but are given in full in the appropriate chapters.

(2) All names of cases have been given in the book without dates and references but are listed with full information in the Index of Cases, as Appendix E.

(3) Throughout the book the term 'land', unless qualified in some way such as 'agricultural land', is used in its normal legal sense as meaning land and buildings thereon.

In writing the book I have been greatly helped by a number of people and my grateful thanks are due to them: to Dr Ivor Seeley, for editorial help and encouragement; to my colleagues in the Department of Surveying at Trent Polytechnic, especially Diane Butler and Roy Mason; and to my wife, for typing and re-typing a complex manuscript. Finally, to the reader who finds in this book the sort of statement described by that great critic, Huckleberry Finn, as '. . . interesting, but steep', may I proffer the encouragement of the White Queen to Alice 
'I can't believe that,' said Alice, 'One can't believe impossible things.' 'Can't you?' said the White Queen, in pitying tones, 'When I was your age, sometimes I've believed six impossible things before breakfast'!

Nottingham, MICHAEL RAYNER

January 1978 